- lower limits on science and engineering professionals coming into the country, or make it more difficult for graduate students to remain in the United States once their education is finished.

Simpson and his staff have been sympathetic to the arguments of young American scientists who complain that a reservoir of foreign graduate students and postdoctoral researchers creates a glut in the market, making it more difficult for US-born scientists to find jobs and keeping salaries down.

Recent reports have supported such argument. David North, a researcher in immigration policy, recently released a study sponsored by the Alfred P. Sloan Foundation called Soothing the Establishment: The Impact of Foreign-Born Scientists and Engineers on America. In it he argues that, even though foreign-born researchers are a highly talented group and make a real contribution to US science, their presence in large numbers relieves what he calls the "American Establishment" from spending more resources on recruiting blacks, Hispanics and members of other minority groups.

Simpson and his staff invited North and several other immigration specialists to his office in Washington late last month for an informal briefing, during which the topic of limiting foreign-born scientists and engineers is said to have come up repeatedly. "I was quite surprised at the intensity of interest in restricting high-skilled immigration," says one participant in the meeting.

But even those seeking increased restrictions admit that the United States must be extremely careful in setting any new policy, as it would not want to cut off the supply of talented engineers and scientists.

Once the debate begins, US postdoctoral researchers keen to keep immigration levels down will be opposed by universities and private companies who want the most talented individuals they can find. And in this arena, says one observer, "all the political clout lines up on the side of the universities". Tony Reichhardt

\title{
Embargo system under siege on Wall St over obesity gene
}

Washington. A \$100-million royalty deal between Amgen, the California-based biotechnology company, and the Rockefeller University in New York, paid off handsomely last week when Amgen's stock surged by 5 per cent in anticipation of results published in the journal Science on the effects of obesity gene products on laboratory mice.

But the way news of the results leaked on Wall Street - sweeping away Science's embargo and boosting Amgen's market capitalization by some $\$ 600$ million in a day has raised questions about the status of embargoed information released in advance by journals for use by science journalists.

"There's always a problem when there is unequal access to information," says Teena Lerner of Lehman Brothers, the analyst whose forewarning of three Science papers was published in her company's daily client newsletter early on Wednesday, 26 July, triggering the rush on Amgen stock.

Told by reporters that the papers - due for publication on Friday, 28 July - would have to be described in news reports on the share movement, Science lifted its embargo on them at $2 \mathrm{pm}$ on 26 July. The story led every television news bulletin that night, and its implications have been the talk of this weight-obsessed nation ever since.

In February, Amgen made a down payment of $\$ 20$ million, with a promise of up to $\$ 80$ million in future royalties, for the exclusive rights to develop products based on Rockefeller's obesity gene work. The agreement followed the announcement by a team of scientists there, led by Jeffrey Friedman and funded by the Howard Hughes Medical Institute, of their successful cloning of an obesity gene (see Nature 372, 425; 1994).
The Science papers - from groups of scientists at Amgen, Rockefeller and at Hoffman-La Roche at Nutley, New Jersey, respectively - confirmed the effects of injecting a protein product of the gene into mice. Lerner's tip to investors focused not on this result, but on the hype she anticipated would accompany it. "The media's inherent overall interest in obesity and weight loss will likely lead to publicity for these scientific studies on Friday," she told them.

With three research teams involved, and pre-publication information in the hands of 400 science reporters, Lerner defends her action on the grounds that "thousands of people in the United States" knew the papers were coming.

But that knowledge may raise some questions for the Securities and Exchange Commission (SEC), which regulates US stock markets. On Tuesday of last week, any member of the public, for example, could buy 'forward options' to purchase Amgen stock at a later date for 63 cents: on Wednesday, such options were worth $\$ 2.63$, and by Thursday, \$4.25.

Insider dealing is by its nature based on stealth, and nothing in the trading record suggests that these options were being bought heavily before Wednesday. An SEC spokesman said that, as a matter of policy, it would not comment on whether an investigation was taking place.

Nan Broadbent, chief of communications at the American Association for the Advancement of Science (AAAS), whichpublishes Science, says that the embargo system would be unaffected by last week's breakdown. "It may be imperfect, but it's the best system we've got," she says.

Colin Macilwain

\section{Developing countries dispute use of figures on climate change impacts}

London. An intergovernmental meeting held to finalize a draft document on the social costs of climate change ended in stalemate last week. Representatives from developing countries attending the meeting refused to endorse a suggestion that global warming would cause twice as much economic damage to the industrialized nations as it would to the rest of the world.

Working Group III of the Intergovernmental Panel on Climate Change (IPCC) has been preparing a draft summary for policy-makers of the damage likely to result from a rise in global temperatures after a doubling of carbon dioxide concentrations.

But the drafting ran into controversy when developing nations, led by India, and China, challenged the use of different criteria for measuring damage in countries of the North and of the South.

The value put on a death in a developed country, for example, was calculated to be 15 times higher than in a less industrialized nation. Such disparities result partly from the conversion of all estimates of loss from national currencies into US dollars. " $\$ 1$ in, say, Cambodia is not the same as $\$ 1$ in the United States," one delegate remarked.

Also at issue is the value to be placed on the 'abatement costs' of global warming. The IPCC committee had calculated that slowing down global warming could be more expensive than merely paying for the damage caused by a doubling in carbon dioxide concentrations (1.5-2 per cent).

But critics such as Aubrey Mayer of the environmental group Global Commons Institute, based in London, disagree.
Mayer argues that cost-benefit analysis should not be used to assess the damage likely to be caused by global warming. "The difficulties of allowing for risk, or assessing the value of a plant or animal species that becomes extinct, are well known," he says.

Narasimhan Sundaraman, secretary to the IPCC, acknowledges disagreements over putting a value on loss of life. But he adds that industrialized nations' representatives are willing to consider alternative methods of modelling.

At the same time, he points out that developing nations have so far failed to propose a single workable alternative. The IPCC working group will attempt to finalize the policy-makers' summary of its report at its next meeting in Montreal, Canada, in October. 